\title{
Hambatan Komunikasi pada Proses Pembelajaran Menggunakan Media Whatsapp Group
}

\author{
Muhammad Sahid \\ ${ }^{1}$ Program Studi Ilmu Komunikasi, Universitas Islam Negeri Alauddin Makassar \\ Email Korespondensi: muhammad.sahid@uin-alauddin.ac.id
}

\begin{abstract}
The learning process is basically the same as the communication process. In simple terms the communication process is the delivery of messages from communicators to communicants. This is in line with the delivery of teaching material from educators to students. The distance learning process that must be carried out by educators during the Covid-19 pandemic requires them to use various teaching methods, one of which is using Whatsapp Group. The learning process using Whatsapp Group can be seen in colleges where almost every subject has a Group in which there are lecturer and students. This study aims to determine the communication barriers experienced by lecturers and students in the learning process using Whatsapp Group. The research method used is a descriptive method with a qualitative approach. This research was conducted on lecturers and students in the Department of Communication Science, Faculty of Da'wah and Communication UIN Alauddin Makassar. The results showed that lecturers and students who were members of the Whatsapp Group subject experienced several obstacles, including (1) sociological barriers, namely barriers related to social status and the relationship between lecturers and students as educators and students. (2) Anthropological barriers are obstacles related to each culture. (3) Psychological barriers, namely obstacles related to the emotional or emotional state of the lecturer or student. (4) Semantic Barriers, namely obstacles related to the use of both verbal and nonverbal language. (5) Mechanical Barriers, are obstacles related to the communication media. (6) Ecological barriers, namely barriers related to the communicator and communicant environment. The results of the study are expected to be able to provide knowledge to educators and students about communication barriers that should be avoided in the learning process using Whatsapp Group.
\end{abstract}

\section{Keywords: Communication Barriers; Whatsapp Group; Learning Process}

\begin{abstract}
Abstrak. Proses pembelajaran pada dasarnya sama dengan proses komunikasi. Secara sederhana proses komunikasi adalah penyampaian pesan dari komunikator kepada komunikan. Hal ini sejalan dengan penyampaian materi ajar dari pendidik kepada peserta didik. Proses pembelajaran jarak jauh yang harus dilakukan oleh pendidik pada masa pandemi Covid-19 mengharuskannya menggunakan berbagai metode pengajaran, salah satunya menggunakan Whatsapp Group. Proses pembelajaran menggunakan Whatsapp Group dapat dilihat pada perguruan tinggi dimana hampir setiap mata kuliah memiliki grup yang didalamnya ada dosen dan mahasiswa. Penelitian ini bertujuan untuk mengetahui hambatan komunikasi yang dialami oleh dosen maupun mahasiswa dalam proses pembelajaran menggunakan Whatsapp Group. Metode penelitian yang digunakan adalah metode deskriptif dengan pendekatan kualitatif. Penelitian ini dilakukan pada dosen dan mahasiswa di jurusan Ilmu Komunikasi Fakultas Dakwah dan Komunikasi UIN Alauddin Makassar. Hasil penelitian menunjukkan bahwa dosen dan mahasiswa yang tergabung dalam Whatsapp Group mata kuliah mengalami beberapa hambatan antara lain (1) hambatan sosiologis, yaitu hambatan yang terkait status sosial dan hubungan antara dosen dan mahasiswa sebagai pendidik dan peserta didik. (2) Hambatan antropolgis, merupakan hambatan yang terkait dengan budaya masing-masing. (3) Hambatan psikologis, yaitu hambatan yangterkait dengan keadaan perasaan atau emosi dari dosen maupun mahasiswa. (4) Hambatan Semantik, yaitu hambatan yang berkaitan dengan penggunaan bahasa baik verbal maupun nonverbal. (5) Hambatan Mekanis, merupakan hambatan yang terkait dengan media komunikasi. (6) Hambatan ekologis, yaitu hambatan yang terkait dengan lingkungan komunikator maupun komunikan. Hasil penelitian
\end{abstract}


diharapkan mampu memberi pengetahuan kepada pendidik maupun peserta didik hambatan komunikasi yang sebaiknya dihindari pada proses pembelajaran menggunakan Whatsapp Group.

Kata kunci: $\underline{\text { Hambatan Komunikasi; Whatsapp Group; Proses Pembelajaran }}$

\section{PENDAHULUAN}

\begin{abstract}
Akhir tahun 2019 merupakan waktu yang akan tercatat dalam sejarah perkembangan dunia ini, utamanya dalam bidang kesehatan. Dunia dilanda sebuah pandemi virus yang ditengarai muncul pertama kali di kota Wuhan Cina. Hampir seluruh negara di dunia merasakan dampak dengan menyebarnya virus tersebut dengan sangat cepat ke seluruh dunia, termasuk di Indonesia. Virus yang diberi nama virus Corona jenis terbaru ini dengan code NCov-2 yang dimana penyakit yang ditimbulkan disebut dengan Covid-19. Awal maret virus ini sudah masuk ke Indonesia dan hingga Desember 2020 sudah 727.122 kasus terkonfirmasi positif Covid-19 (Ramadhan, 2020).
\end{abstract}

Selain dari aspek kesehatan, hampir seluruh aspek kehidupan masyarakat terpengaruh dengan adanya pandemi ini, seperti ekonomi, sosial, dan juga pendidikan. Salah satu himbauan dari pemerintah kepada masyarakat untuk mengurangi penularan virus corona adalah dengan menjaga jarak dan tidak berkerumun. Himbauan ini membuat sangat mempengaruhi kehidupan masyarakat yang telah terbiasa berkerumun seperti di tempat perbelanjaan, tempat ibadah serta juga pada sarana pendidikan. Hal itu mengakibatkan sistem pendidikan kita yang telah terbiasa mengadakan proses pembelajaran dalam ruang kelas harus ditangguhkan demi untuk menghindari kerumunan. Hal ini tentunya membuat lembaga pendidikan mulai dari pendidikan dasar hingga pendidikan tinggi mencari solusi untuk tetap menjalankan proses pembelajaran meski bukan dilakukan di ruang kelas. Selain itu, berbagai metode pembelajaran pun harus dapat dikuasai oleh pengajar. Hal itu karena metode mengajar mempengaruhi motivasi belajar sehingga pencapaian belajar bisa maksimal (Khairunnisah, 2018). Termasuk juga metode mengajar secara jarak jauh atau menggunakan jaringan internet.
Pembelajaran jarak jauh dalam hal ini menggunakan jaringan internet menjadi pilihan pada proses pembelajaran agar tetap berjalan. Hal ini bukanlah sesuatu yang sulit untuk diterapkan mengingat kemajuan teknologi komunikasi dan informasi saat ini sudah mendukung proses pembelajaran jarak jauh. Selain mengunakan platform e-learning yang sudah banyak beredar di internet, pengajar juga menggunakan media online lain dalam melakukan proses belajar mengajar. Media yang awalnya digunakan untuk memperlancar komunikasi jarak jauh yang berupa program aplikasi pun menjadi salah satu pilihan dalam melakukan proses pembelajaran online. Beberapa aplikasi yang berbasis digital yang biasa digunakan dalam proses pembelajaran antara lain Zoom Meeting, Google Meet, Telegram, Whatsapp serta beberapa media sosial ataupun aplikasi percakapan lainnya.

Whatsapp menjadi salah satu media komunikasi dalamm proses pembelajaran, utamanya untuk menjadi media komunikasi antara pengajar dan peserta didik, misalnya antara dosen dan mahasiswa. Whatsapp menjadi salah satu aplikasi percakapan online yang banyak digunakan masyarakat. Berdasarkan berita yang dihimpun oleh okezone.com, jumlah pengguna aktif Whatsapp di pada Januari 2020 mencapai 1,5 miliar pengguna (Untari, 2020). Salah satu fitur unggulan Whatsapp adalah Whatsapp Group yang memungkinkan banyak orang dapat berkuminaksi dalam satu forum atau grup. Misalnya, pada perguruan tinggi hampir semua kelas mata kuliah memiliki Whatsapp Group untuk mempermudah komunikasi antara dosen dengan mahasiswa. Faktor pendukung yang membuat Whatsapp dipilih sebagai media pembelajaran adalah karena fitur yang dimiliki beragam, mulai dari chatting, kirim file, mengirim gambar atau foto, video dan juga yang lainnya (Wahyuni, 2018). 
1. Pesan (chatting): pengguna dapat memanfaatkan koneksi internet untuk berkirim pesan kepada pengguna lain;

2. ChatGrup: pengguna dapat membuat grup yang terdiri dari nomor ponsel yang sudah terdaftar pada Whatsapp untuk memudahkan berkomunikasi antar anggota dalam grup.

3. WhatsappWeb dan Desktop: pengguna dapat mengirim dan menerima pesan Whatsapp langsung dari browser komputer atau langsung pada komputer dengan syarat Whatsapp pada telepon genggam tetap aktif.

4. Panggilan Suara dan Video Whatsapp: pengguna dapat melakukan panggilan suara dan panggilan video (video call) di seluruh dunia menggunakan koneksi internet ponsel atau wi-fi.

5. Foto dan Video: pengguna dapat berbagi foto dan video diantara pengguna baik personal maupun dalam grup.

6. Mengirim lampiran (foto, video dan dokumen)

7. Enkripsi end to end: sistem keamanan untuk pengguna

Oleh karena itu, penggunaan Whatsapp Group selain sebagai media komunikasi juga telah menjadi media pembelajaran. Dosen dapat mengirimkan materi perkuliahan dalam bentuk dokumen, audio atupun video pembelajaran kepada mahasiswa yang ada dalam grup perkuliahan. Hal ini dapat diartikan bahwa Whatsapp Group dapat menggantikan ruang kelas fisik ke dalam bentuk virtual dimana dosen dapat memberi materi serta berkomunikasi dengan semua mahasiswa dalam kelasnya menggunakan aplikasi Whatsapp Group. Whatsapp Group dapat dimanfaatkan sebagai media pembelajaran dimana pendidik dan peserta didik dapat bertukar informasi (Pustikayasa, 2019). Selain itu pendidik dapat membuat forum diskusi pada Whatsapp Group dengan berbagai fitur yang dapat mendukung kegiatan diskusi. Penggunaan Whatsapp Group sebagai media komunikasi dan pembelajaran bagi dosen tentunya tidak serta merta berjalan mulus begitu saja.
Pada dasarnya proses pembelajaran sama seperti proses komunikasi. Secara sederhana konsep komunikasi adalah proses penyampaian pesan dari komunikator kepada komunikan (Fagir, 2018). Komunikasi merupakan hal yang dianggap penting dan dan dibutuhkan untuk setiap untuk setiap kehidupan manusia (Gani et al., 2020) begitupun komunikasi yang tergambar pada proses pembelajaran, tanpa adanya komunikasi maka bisa dikatakan tidak ada pula proses pembelajaran. Dalam hal proses pembelajaran pada perguruan tinggi dapat dikatakan bahwa dosen sebagai komunikator, mahasiswa sebagai komunikan, dan materi ajarnya merupakan isi pesan yang disampaikan. Dalam penyampaian pesan, maka tidak menutup kemungkinan terjadi hambatan prosesnya, baik itu dari komunikator maupun dari komunikan. Hambatan komunikasi dapat dikatakan sebagai penghalang atau hal-hal yang dapat mempengaruhi kelancaran proses komunikasi.

Hambatan komunikasi dapat terjadi dalam proses pembelajaran karena kemampuan dosen dalam menyampaikan pesan berbeda-beda. Ada yang mampu menyampaikan pesan dengan baik adapula yang kesulitan dalam merangkai dan menyampaikan pesan kepada mahasiswa. Begitupun dengan mahasiswa ada yang mampu menangkap pesan dengan baik adapula yang kesulitan menangkap pesan, ditambah dengan penggunaan Whatsapp sebagai media komunikasi dalam pembelajaran. Hambatan komunikasi yang dapat terjadi pada proses pembelajaran menggunakan Whatsapp Group antara lain:

1. Hambatan Sosiologis, yaitu hambatan komunikasi yang menyangkut status sosial seseorang.hambatan ini terkait bagaimana cara orang berkomunikasi dengan orang lain berdasarkan usia, jenis kelamin, tingkat kekayaan, tingkat kekuasaan dan status sosial lainnya.

2. Hambatan Antropologis, yaitu adanya perbedaan budaya yang dibawa oleh setiap orang. Hambatan ini menunjukkan bahwa budaya yang dibawa setiap orang 
bisa saja menjadi hambatan dalam berkomunikasi secara efektif.

3. Hambatan Psikologis, merupakan hambatan yang terkait dengan kondisi psikologis komunikator maupun komunikan, misalnya keadaan emosi atau perasaan dan prasangka dari komunikan.

4. Hambatan Semantik, yaitu hambatan yang berkaitan dengan bahasa yang digunakan oleh komunikator dan pemahaman pesan oleh komunikan.

5. Hambatan Mekanis, merupakan hambatan yang dijumpai pada penggunaan media komunikasi, misalnya terjadinya kerusakan pada media komunikasi yang digunakan.

6. Hambatan Ekologis, yaitu hambatan yang disebabkan oleh adanya gangguan pada lingkungan sekitar komunikator ataupun komunikan. Hambatan ini misalanya suara bising atau suara riuh dari sekitar. Situasi ini bisa saja dihindari komunikator dengan berada jauh dari sumber gangguan pada saat proses komunikasi berlangsung (Hidayah, 2019).

Tujuan dari penelitian ini adalah untuk mengetahui hambatan komunikasi pada proses pembelajaran menggunakan media Whatsapp Group. Hasil penelitian ini diharapkan mampu menjadi referensi dan bahan pertimbangan bagi pengajar baik itu guru maupun dosen dalam penggunaan Whatasapp Group sebagai media pembelajaran. Peneliti berharap dapat memberikan gambaran mengenai apa saja yang menjadi hambatan dan harus dihindari oleh pengajar maupun peserta didik ketika menggunakan Whatsapp Group sebagai media pembelajaran.

\section{METODE PENELITIAN}

Penelitian ini menggunakan jenis penelitian deskriptif melalui pendekatan kualitatif. Peneliti ingin mengetahui gambaran fenomena yang ada dengan menggunakan metode ini tidak untuk menguji hipotesis, tetapi peneliti hanya mengambarkan keadaan yang mencerminkan adanya hambatan komunikasi yang terjadi dalam pembelajaran menggunakan Whatsapp Group. Objek dari penelitian ini merupakan sebuah fenomena yang nantinya peneliti akan deskripsikan melalui wawancara terhadap subyek penelitian. Pengumpulan data dilakukan dengan melakukan observasi, wawancara serta menggunakan dokumentasi pada sumber data penelitian.

Penelitian ini dilakukan pada Jurusan Ilmu Komunikasi Fakultas Dakwah dan Komunikasi UIN Alauddin Makassar. Berdasarkan hasil observasi awal maka subyek penelitian yang akan diwawancarai adalah beberapa orang dosen pada jurusan Ilmu Komunikasi UIN Alauddin Makassar yang menggunakan Whatsapp Group pada kelas perkuliahannya, dalam hal ini dipilih tiga orang dosen. Selain itu, mahasiswa juga menjadi subyek penelitian agar peneliti mengetahui hambatan komunikasi pada mahasiswa melalui pembelajaran menggunakan Whatsapp Group. Mahasiswa yang akan diwawancarai merupakan mahasiswa yang menjadi peserta mata kuliah dari ketiga orang dosen yang diwawancarai dengan sebanyak dua orang mahasiswa dari tiap dosen.

\section{HASIL DAN PEMBAHASAN}

Dalam penggunaan Whatsapp Group sebagai media pembelajaran, ada beberapa hambatan komunikasi yang terjadi. Baik itu dari komunikator maupun dari komunikannya, atu juga hambatan yang berasal dari media komunikasi itu sendiri. Bisa dikatakan bahwa penggunaan Whatsapp tidak selalu sesuai dengan harapan dari dosen maupun mahasiswa. Berdasarkan hasil wawancara dengan dosen dan mahasiswa maka hambatan komunikasi tersebut dikategorikan sebagai berikut:

\section{Hambatan Sosiologis}

Hambatan sosiologi yang dimaksud disini adalah hambatan yang menyangkut status sosial atau hubungan antara dosen dan mahasiswa. Berdasarkan wawancara yang telah dilakukan pada dosen, perbedaan status antara dosen dan mahasiswa membuat mereka kesulitan ketika mencoba untuk membuat mahasiswa merasa dekat dengan dosennya 
pada proses pembelajaran di Whatsapp Group. Hal itu dikarenakan dosen kesulitan untuk mengetahui apakah mahasiswa ketika aktif di Whatsapp Group sedang dalam keadaan santai atau serius. Dosen menjadi kesulitan untuk merangkai pesan kepada mahasiswa di Whatsapp Group. Berbeda ketika berada di ruang kelas, dosen mampu mengamati kondisi emosi mahasiswa berdasarkan komunikasi nonverbal yang ditunjukkan, sehingga dosen mampu menyiasati metode perkuliahan dengan berusaha membuat suasana kelas menjadi menyenangkan bagi dosen maupun bagi mahasiswa. Sebagaimana menurut Dale G. Leathers bahwa salah satu alasan mengapa pesan nonverbal sangat signifikan adalah karena perasaan dan emosi ketimbang pesan verbal (Kusumawati, 2016). Selain itu, faktorfaktor nonverbal sangat memnentukan makna dalam komunikasi. Kita seringkali menyampaikan gagasan dan pikiran kita melalui ketika melakukan komunikasi tatap muka dengan melalui pesan-pesan nonverbal. Hal ini menyebabkan orang lain pun akan menginterpretasi pesan yang disampaikan dengan melihat dan membaca sendiri pesan nonverbal yang disampaikan. Bentuk komunikasi inilah yang tidak dapat ditemukan pada proses komunikasi dalam pembelajaran melalui Whatsapp Group.

Begitu pula dengan mahasiswa, mereka menjadi canggung untuk berkomunikasi di Whatsapp Group yang di dalamnya ada dosen mata kuliah. Mahasiswa menganggap bahwa mereka takut untuk mengirim pesan teks yang sifatnya untuk bertanya ataupun mengomentari proses pembelajaran yang dilakukan dosen karena tidak mengetahui sifat atau karakter dosen itu sendiri. Karakter dari setiap dosen berbeda satu sama lain. Sebagian dosen senang apabila merasa dekat dengan mahasiswanya adapula yang seperti memberi batasan pada mahasiswa dalam berkomunikasi. Karakter dosen dapat pula dikategorikan ada yang memiliki karakter yang santai dan adapula yang karakternya serius dan hanya ingin membahas materi kuliah saja di dalam Whatsapp Group. Apabila terjadi miskomunikasi antara mahasiswa dan dosen yang berawal dari kesalahan dalam menebak karakter dosen, maka bisa saja terjadi konflik antara dosen dan mahasiswa.

\section{Hambatan Antropologis}

Hambatan antropologis dapat diartikan sebagai hambatan komunikasi yang terjadi akibat adanya perbedaan budaya yang dimiliki antara dosen dan mahasiswa. Mengingat bahwa dalam Whatsapp Group antara dosen dan mahasiswa tidak saling mengetahui seperti apa kebudayaan masingmasing, bisa saja budaya yang dibawa berbeda-beda. Hasil wawancara menunjukkan bahwa ada beberapa karakteristik budaya yang kadang menjadi penghambat dosen ketika berkomunikasi dengan mahasiswa, misalnya kesadaran waktu, nilai dan norma, serta sikap. Dosen menganggap mahassiwa terkadang tidak mampu menyesuaikan waktu perkuliahan dengan baik di Whatsapp Group untuk mengikuti materi kuliah, ada mahasiswa yang tepat waktu memberitahu kehadirannya adapula yang sangat terlambat dengan alasan terjadi gangguan pada perangkatnya. Selain itu, sebagian mahasiswa dianggap tidak memiliki aturan jam yang baik untuk mengirim pesan di Whatsapp. Sebagian dari mereka dikatakan kadang mengirim pesan pada jam yang seharusnya dosennya sudah istirahat dan tidak meladeni pembahasan kuliah di Whatsapp Group. Sama halnya dengan norma dan nilai yang dianut dosen menurutnya tidak semua dapat dimengerti oleh mahasiswa. Begitupun dengan sikap mahasiswa yang terkadang menganggap sebuah Whatsapp Group perkuliahan sama seperti grup lain yang dimiliki bersama teman-temannya yang tidak ada dosen di dalamnya. Mahasiswa dianggap terkadang mengirim pesan seenaknya saja tanpa menghiraukan bahwa di dalam grup tersebut ada dosen yang harus dihormati.

Sementara itu, mahasiswa menganggap bahwa faktor antropologis bisa dikatakan hanya menjadi hambatan yang sifatnya sebagai hambatan kecil saja. Mereka beranggapan bahwa perbedaan budaya tidak terlalu menghambat mereka dalam berkomunikasi dengan dosen pada Whatsapp 
Group. Berdasarkan hasil wawancara mahasiswa mengatakan bahwa hal yang menjadi poin utama mereka ketika mengirim pesan di Whatsapp Group adalah tersampaikannya pesan kepada dosen. Mereka menganggap bahwa sudah seharusnya dosen mengerti dengan keadaan pandemi saat ini sehingga komunikasi melalui Whatsapp Group seharusnya tidak perlu memikirkan aspek budaya. Mahasiswa beranggapan bahwa kedudukan dosen dalam Whatsapp Group adalah menjadi pengajar bagi mereka, sehingga apapun yang ingin disampaikan atau ditanyakan pada dosen dapat dilakukan melalui pesan Whatsapp tanpa harus memikirkan seperti apa budaya yang dianut oleh dosen mata kuliah. Sudah sewajarnya dosen menjawab setiap pertanyaan atau pesan yang dikirimkan oleh mahasiswa pada Whatsapp Group perkuliahan.

\section{Hambatan Psikologis}

Hambatan psikologis dapat diartikan sebagai hambatan yang terjadi pada diri komunikator ataupun pada komunkan. Proses komunikasi akan berjalan dengan lancar apabila komunikator menyampaikan pesan dan diterima dengan baik oleh komunikan. Namun, berbeda dengan keadaan apabila komunikasinya dilakukan melalui media seperti Whatsapp. Dosen tidak tahu keadaan mahasiswanya apakah sedang sedih, sedang senang atau mungkin sedang marah. Hal ini dapat menjadi hambatan untuk efektifnya komunikasi dosen kepada mahasiswa pada Whatsapp Group. Penyampaian pesan, termasuk bahan ajar bisa saja akan diabaikan oleh mahasiswa jika keadaanya sedang tidak baik untuk melakukan perkuliahan. Hal inilah yang menjadi kendala dimana dosen tidak mampu melihat kondisi dan situasi emosi dari mahasiswanya. Lain lagi jika dilihat dari sisi psikologi dosen. Ketika dosen sedang dalam situasi emosi yang tidak baik untuk melakukan komunikasi dan pembelajaran maka bisa mengakibatkan proses komunikasi yang tidak efektif. Sama halnya seperti dosen yang tidak tahu situasi psikis dari mahasiswanya saat proses perkuliahan atau komunikasi pada Whatsapp Group, mahasiswa pun seperti itu.
Seorang mahasiswa akan mengirimkan begitu saja pesan melaluii Whatsapp kepada dosennya tanpa mengetahui situasi emosi dari dosennya. Hal ini dapat membuat dosen merasa terganggu apabila mereka dalam keadaan emosi yang kurang baik kemudian harus melayani pesan yang dikirimkan oleh mahasiswa melalui Whatsapp. Hal ini menyulitkan mahasiswa untuk berkomunikasi dengan baik dengan dosennya. Tentu akan terlihat tidak sopan jika harus menanyakan kondisi emosi dosen terlebih dahulu sebelum mengirimkan pesan.

\section{Hambatan Semantik}

Hambatan semantik dapat dikatakan sebagai hambatan yang ada karena faktor penggunaan bahasa. Seorang komunikator harus benar-benar memperhatikan faktor ini karena bisa saja salah pengucapan, atau salah ketik dapat menimbulkan salah pengertian atau salah tafsir dari komunikan. Hal ini dapat menimbulkan adanya kesalahan komunikasi atau miskomunikasi. Adapun bahasa yang dimaksud sebagai hambatan semantik adalah bahasa verbal dan bahasa nonverbal dalam komunikasi. Proses komunikasi antara dosen dan mahasiswa tidak terlepas dari penggunaan bahasa nonverbal, hal tersebut dapat dilihat pada penggunaan emoji atau stiker yang merupakan gambar yang dapat dimaknai oleh komunikan.

Penggunaan emoji dan stiker dalam pesan menurut dosen sesungguhnya mampu mewakili bahasa verbal yang berupa ketikan teks. Namun, hal yang menjadi hambatan ketika dosen tidak tahu apa makna dari simbol emoji atau stiker yang dikirim oleh mahasiswa. Ketika hal ini terjadi, maka dosen akan berusaha menginterpretasi sendiri maksud atau arti dari simbol itu. Kesalahan dalam memaknai simbol ini terkadang mengakibatkan adanya salah pengertian antara dosen dan mahasiswa serta dapat pula mengakibatkan adanya konflik ketika simbol yang dikirim dianggap tidak etis atau kurang sopan. Untuk menghindari hambatan ini, dosen harus mencari referensi dan menanyakan maksud dari simbol yang dikirim oleh mahasiswa agar tidak terjadi ketidakpastian. Sebagaimana strategi 
pengurangan ketidakpastian yang diungkapkan oleh Charles Berger, strategi pengurangan ketidakpastian yaitu pertama strategi aktif, yang dilakukan dengan mencari sendiri informasi makna dari pesan yang disampaikan tanpa berkontak langsung dengan komunikatornya. Kedua strategi pasif, yaitu mengamati simbol atau pesan yang disampaikan hingga dapat menginterpretasikan sendiri makna pesan berdasarkan hasil pengamatan. Ketiga strategi interaktif, yaitu menanyakan langsung kepada komunikator mengenai makna dari simbol atau pesan yang telah dikirim (Febriani \& Iqbal, 2015).

Hal yang sama diungkapkan oleh mahasiswa bagaimana mereka juga terkadang sulit untuk memaknai simbol atau emoji yang dikirim baik itu dari dosen maupun dari teman sendiri dalam Whatsapp Group. Mahasiswa mengirimkan emoji dan stiker sebagai pengganti dari bahasa verbal karena dianggap lebih mudah dalam mewakili emosi mereka. Mahasiswa dalam memaknai simbol emoji atau stiker pada Whatsapp biasanya mengamati penggunaannya, sehingga semakin sering digunakan maka akan semakin mudah untuk menginterpretasikan maknanya. Hal itu karena mereka dapat menginterpretasikan makna berdasarkan dari konteks percakapan atau pembahasan yang berjalan pada Whatsapp Group.

\section{Hambatan Mekanis}

Hambatan mekanis diartikan sebagai segala bentuk hambatan yang sifatnya ada pada media yang digunakan pada proses komunikasi. Whatsapp yang dapat dikatakan sebagai media komunikasi, dapat digunakan dengan dukungan dari hal mekanis lain seperti perangkat yang digunakan dalam menggunakan aplikasi Whatsapp. Menurut dosen yang telah diwawancarai, ada beberapa hambatan mekanis yang terkadang didapati dalam penggunaan Whatsapp Group sebagai media pembelajaran. Hambatan-hambatan tersebut antara lain perangkat yang digunakan, ketersediaan aplikasi pendukung yang lain, serta penggunaan aplikasi Whatsapp. Hambatan yang terjadi pada perangkat menurut dosen seperti ketersediaan tenaga pada baterai telepon genggam yang digunakan. Ketika jauh dari sumber listrik dan telepon genggam yang digunakan tenaga baterainya hampir habis maka akan kesulitan untuk memberi perkuliahan. Perkuliahan dapat putus begitu saja, jika baterai telepon genggam sudah habis. Selain itu, penggunaan aplikasi lain yang mendukung proses pembelajaran pada Whatsapp Group juga sangat mempengaruhi proses perkuliahan. Aplikasi pengolah dokumen, pengolah presentasi atau sejenisnya. Terkadang materi perkuliahan yang dimiliki oleh dosen berupa dokumen, dokumen presentasi, atau bahkan video pembelajaran. Hal yang menjadi hambatan ketika dosen tidak terlalu mengetahui bagaimana mengirimkan materi perkuliahan tersebut ke dalam Whatsapp Group. Selain itu, adanya batasan pengiriman file juga dianggap menghambat proses komunikasi dalam pembelajaran melalui Whatsapp. Terkadang dosen harus mencari cara lain untuk mengirimkan materi pembelajaran kepada mahasiswa apabila ukuran file yang ingin dikirim tidak dapat diakomodir oleh Whatsapp. Adapun terkait penggunaan Whatsapp, hambatan yang diperoleh adalah belum maksimalnya penggunaan Whatsapp oleh dosen. Masih ada beberapa fitur Whatsapp yang dapat mempermudah proses komunikasi antara dosen dan mahasiswa dalam grup tapi belum digunakan oleh dosen. Hal tersebut dikarenakan tidak semua dosen mengetahui dengan baik semua fitur yang dapat digunakan pada Whatsapp.

Sejalan dengan dosennya, mahasiswa juga mengalami beberapa hambatan mekanis dalam berkomunikasi pada Whatsapp Group perkuliahan. Hambatan yang sama juga dialami oleh mahasiswa seperti keadaan perangkat, aplikasi pendukung, penggunaan Whatsapp. Menurut mahasiswa yang telah diwawancarai, tidak semua mahasiswa memiliki perangkat yang mendukung untuk menjalankan aplikasi Whatsapp dengan baik dan lancar. Beberapa mahasiswa memiliki telepon genggam dengan spesifikasi yang standar sehingga terkadang Whatsapp yang digunakan mengalami masalah dalam proses 
jalannya aplikasi. Selain itu, spesifikasi telepon genggam mahasiswa yang standar terkdang juga menyulitkan mereka ketika ingin menyimpan file materi ajar yang dirimkan oleh dosen. Selanjutnya tentang aplikasi lain yang digunakan dalam proses pembelajaran, seperti pengolah dokumen ataupun presentasi. Pada sebagian mahasiswa yang perangkatnya kesulitan membuka Whatsapp, tentu akan lebih sulit lagi jika harus menggunakan aplikasi tambahan untuk membuka file materi ajar yang dikirimkan oleh dosen. Adapula mahasiswa yang mengalami hambatan pada ketersediaan pulsa data untuk membuka Whatsapp. Seperti yang diketahui Whatsapp dapat diakses menggunakan jaringan internet, sedangkan tidak semua mahasiswa selalu memiliki ketersediaan pulsa data untuk menggunakan jaringan internet. Selain kendala tersebut, hambatan lain yang ada pada mahasiswa adalah masih adanya mahasiswa yang belum mengetahui keseluruhan fitur yang ada pada Whatsapp.

\section{Hambatan Ekologis}

Hambatan ini merupakan hambatan yang terjadi karena adanya gangguna di lingkungan sekitar komunikator ataupun komunikan. Pada penggunaan Whatsapp hambatan ekologis yang biasa didapati baik dari dosen ataupun mahasiswa adalah ketika mereka mengirimkan pesan suara. Pengiriman pesan melalui suara ini terkadang terganggu dengan adanya suara-suara bising atau riuh di sekitar dosen atau mahasiswa. Untuk menghindari hal tersebut maka biasanya harus menghindari ataupun menjauh dari tempat yang memiliki gangguan tersebut. Hal ini sulit terjadi ketika dosen ataupun mahasiswa sedang berada di lokasi atau tempat yang sulit untuk mencari tempat yang sunyi atau bebas dari gangguan. Hal itu karena pelaksanaan kuliah melalui Whatsapp Group memungkinkan dosen maupun mahasiswa mengakses perkuliahan dari mana saja dan bisa sambil melakukan aktivitas lain.

Hal lain yang bisa dikatakan sebagai hambatan ekologis adalah tersedianya infrastruktur yang mendukug lancarnya proses pembelajaran melalui Whatsapp
Group. Infrastruktur yang dimaksud adalah jaringan internet yang merupakan syarat mutlak untuk menjalankan aplikasi Whatsapp. Berbagai operator seluler telah menyediakan kuota internet dengan berbagai paket besaran kuota. Adapula signal wi-fi yang biasanya bisa diakses publik di tempat-tempat tertentu. Hal yang menjadi hambatan adalah karena tidak semua daerah dapat dijangkau oleh signal atau jaringan dari operator seluler maupun penyedia layanan wi-fi. Pada negara kita di Indonesia kesenjangan digital masih terjadi di berbagai tempat. Masih ada beberapa tempat yang kita tidak bisa mengakses jaringan internet, bahkan untuk melakukan panggilan telepon sekalipun. Beberapa mahasiswa bisa dikatakan berada pada lokasi yang seperti itu, sehingga hal ini tentu akan menghambat proes mereka dalam menerima materi ajar pada Whatsapp Group.

\section{KESIMPULAN}

Penelitian ini dilakukan untuk mengetahui hambatan komunikasi pada penggunaan Whatsapp Group sebagai media pembelajaran. Hasil penelitian menunjukkan bahwa dosen dan mahasiswa yang tergabung dalam Whatsapp Group mata kuliah mengalami beberapa hambatan antara lain (1) hambatan sosiologis, yaitu hambatan yang terkait status sosial dan hubungan antara dosen dan mahasiswa sebagai pendidik dan peserta didik. (2) Hambatan antropolgis, merupakan hambatan yang terkait dengan budaya masing-masing. Dosen dan mahasiswa punya budaya masing-masing yang terkadang dalam Whatsapp Group menjadi hal yang dianggap tidak etis oleh satu sama lain. (3) Hambatan psikologis, yaitu hambatan yangterkait dengan keadaan perasaan atau emosi dari dosen maupun mahasiswa. Hambatan ini sangat sulit untuk dihindari karena baik dosen maupun mahasiswa akan sulit untuk saling menebak keadaan emosi satu sama lain saat berkomunikasi. (4) Hambatan Semantik, yaitu hambatan yang berkaitan dengan penggunaan bahasa baik verbal maupun nonverbal. Pada Whatsapp penggunaan emoji dan stiker sebagai bentuk komunikasi nonverbal 
terkadang sulit untuk dimaknai oleh komunikan. (5) Hambatan Mekanis, merupakan hambatan yang terkait dengan media komunikasi. Media komunikasi yang dimaksud adalah perangkat yang digunakan untuk mengakses Whatsapp. Tidak semua perangkat dapat dengan lancar digunakan untuk mengakses Whatsapp. (6) Hambatan ekologis, yaitu hambatan yang terkait dengan lingkungan komunikator maupun komunikan. Baik dosen maupun mahasiswa tidak dapat mengatur keadaan sekitar agar mereka dapat mengirim pesan tanpa danya gangguan dari lingkungan sekitarnya. Begitupun dengan ketersediaan jaringan internet, tidak semua tempat dapat digunakan mengakses Whatsapp karena ada beberapa tempat yang tidak dijangkau oleh jaringan internet.

\section{SARAN}

Berdasarkan hasil penelitian, hambatanhambatan komunikasi yang telah dijabarkan sebelumnya bukanlah sesuatu yang tidak bisa dihindari. Oleh karena itu, penulis berharap dalam proses pembelajaran baik pendidik maupun peserta didik sebaiknya mampu menghindari hambatan-hambatan komunikasi yang dapat terjadi pada penggunaan Whatsapp Group sebagai media pembelajaran, sehingga kesalahpahaman dan miskomunikasi dapat terhidanrkan.

\section{UCAPAN TERIMA KASIH}

Ucapan terima kasih penulis sampaikan kepada semua pihak yang terlibat dalam penelitian ini. Kepada dosen dan mahasiswa dari jurusan Ilmu Komunikasi UIN Alauddin Makassar yang bersedia menjadi informan. Selain itu ucapan terima kasih diampaikan pula kepada pengelola jurnal JISIP :Jurnal Ilmu Sosial dan Pendidikan yang telah memberi kesempatan untuk ikut berkontribusi sebagai penulis.

\section{DAFTAR PUSTAKA}

Fagir, A. (2018). Karakter Sekolah Bermutu Melalui Mediasi Komunikasi Kepemimpinan. JISIP: Jurnal Ilmu Sosial Dan Pendidikan, 2(2), 162170.

http://ejournal.mandalanursa.org/ind
ex.php/JISIP/article/view/577/560

Febriani, N. W., \& Iqbal, F. (2015). Strategi Pengurangan Ketidakpastian Dalam Sistem Komunikasi Interpersonal (Studi Fenomenologi pada Peserta On The Job Training Program Ke Jepang dari PT. Hitachi Construction Machinery Indonesia Periode Pemberangkatan Tahun 2009-2012). Jurnal Komunikasi PROFETIK, 8(2), 65-80.

Gani, N., Fitriana, A. D., Sila, A. M., Fitriani, R., Yuliarti, A., \& Sahid, M. (2020). Covid 19 Dalam Bingkai Komunikasi. In T. Bahfiarti (Ed.), IAIN Pare-Pare Nusantara Pres. IAIN Parepare Nusantara Press.

Hidayah, A. N. (2019). Analisis Hambatan Komunikasi Pada Pembelajaran Ekonomi Materi Persamaan Akuntansi Di Madrasah Aliyah Darul Hikmah Pekanbaru. UIN Sultan Syarif Kasim Riau.

Khairunnisah, N. A. (2018). Pengaruh Metode Mengajar Guru Kelas Terhadap Motivasi Belajar Siswa. JISIP: Jurnal Ilmu Sosial Dan Pendidikan, 2(2), 202-203. http://ejournal.mandalanursa.org/ind ex.php/JISIP/article/view/572/555

Kusumawati, T. I. (2016). Komunikasi Verbal Dan Nonverbal. Jurnal Pendidikan Dan Konseling.

Pustikayasa, I. M. (2019). Grup WhatsApp Sebagai Media Pembelajaran. Widya Genitri: Jurnal Ilmiah Pendidikan, Agama Dan Kebudayaan Hindu, 10(2), 53-62. https://doi.org/10.36417/widyagenitri .v10i2.281

Ramadhan, A. (2020). UPDATE: Bertambah 7.903, Kasus Covid-19 di Indonesia Kini 727.122. Kompas.Com. https://nasional.kompas.com/read/20 20/12/29/15294331/updatebertambah-7903-kasus-covid-19-diindonesia-kini-727122

Untari, P. H. (2020). Jumlah Pengguna WhatsApp di Dunia Capai 1,5 Miliar. Okezone.Com. 
Terakreditasi Peringkat 5 (No. SK: 85/M/KPT/2020)

https://techno.okezone.com/read/202

0/01/31/207/2161194/jumlah-

pengguna-whatsapp-di-dunia-capai-

1-5-miliar?page $=1$

Wahyuni, N. (2018). Peran Penggunaan Grup

Whatsapp Dalam Proses Belajar

Mengajar Di SMK Negeri 2

Banjarmasin. MUTAKALLIMIN: Jurnal

Ilmu Komunikasi, 1(2), 19-26.

https://ojs.uniska-

bjm.ac.id/index.php/mutakallimin/article

/view/3411/2289 